This is an electronic reprint of the original article. This reprint may differ from the original in pagination and typographic detail.

Author(s): Horila, Tessa; Valo, Maarit

Title: $\quad$ Yhteinen vuorovaikutusosaaminen tiimissä

Year: $\quad 2016$

Version:

Please cite the original version:

Horila, T., \& Valo, M. (2016). Yhteinen vuorovaikutusosaaminen tiimissä. Prologi : puheviestinnän vuosikirja 2016, 2016, 46-58.

All material supplied via JYX is protected by copyright and other intellectual property rights, and duplication or sale of all or part of any of the repository collections is not permitted, except that material may be duplicated by you for your research use or educational purposes in electronic or print form. You must obtain permission for any other use. Electronic or print copies may not be offered, whether for sale or otherwise to anyone who is not an authorised user. 
Artikkeli

Prologi - puheviestinnän

\section{Yhteinen vuorovaikutusosaaminen tiimissä}

\author{
Tessa Horila \\ väitöskirjatutkija, FM \\ Jyväskylän yliopisto \\ tessa.horila@jyu.fi
}

\author{
Maarit Valo \\ professori, FT \\ Jyväskylän yliopisto \\ maarit.a.valo@jyu.fi
}

\section{Tiivistelmä}

Tässä teoreettisessa artikkelissa esitellään uusi yhteisen vuorovaikutusosaamisen käsite. Se soveltuu erityisesti työelämän tiimien vuorovaikutusosaamisen tarkasteluun. Vuorovaikutusosaamista on määritelty ja tutkittu paljon. Tiimien osaamistutkimus on kuitenkin ollut vähäisempää kuin tutkimus vuorovaikutusosaamisesta esimerkiksi kahdenvälisessä vuorovaikutuksessa tai esiintymisessä. Lisäksi tutkimus on ollut teoreettisesti puutteellista.

Käsitteellistyksessä edetään nelivaiheisesti. Ensin tehdään synteesiä ryhmä- ja tiimivuorovaikutusosaamisen teoreettisista lähtökohdista ja empiirisestä tutkimuksesta. Toiseksi nostetaan esille tutkimuksen keskeisiä teoreettisia puutteita, jotka estävät vuorovaikutusosaamisen syvemmän ymmärryksen työelämän kompleksisessa tiimiviestinnässä. Kolmanneksi esitellään puheviestintätieteen lähialoilla tehdyn monitasoisen tiimitutkimuksen edistysaskeleita. Erityisesti käsittelemme emergenssin perusperiaatteiden hyötyä tiimi-ilmiöiden tutkimukselle. Neljänneksi tarkastelemme yhteisen vuorovaikutusosaamisen käsitettä. Tarkoitamme sillä emergenttiä vuorovaikutusosaamista, joka sijaitsee sekä yksilö- että ryhmätasolla, kehittyy vuorovaikutusprosesseissa ja on luonteeltaan temporaalista eli aikasidonnaista.

Erittelemme uuden käsitteen mahdollisuuksia ja etuja tutkimukselle. Yhteisen vuorovaikutusosaamisen tutkimus täydentäisi ryhmäviestinnän teoreettista tietämystä. Käsite toisi vuorovaikutusosaamisen tutkimuksen osaksi monitasoisen tiimitutkimuksen tieteidenvälistä keskustelua.

ASIASANAT: monitasoisuus, ryhmäviestintä, tiimiviestintä, vuorovaikutusosaaminen, yhteinen vuorovaikutusosaaminen 


\section{Johdanto}

Suomalaisista työntekijöistä yli kuusikymmentä prosenttia työskentelee säännöllisesti yhdessä tai useammassa tiimissä. Tiimissä työskenteleminen voi vaikuttaa positiivisesti moniin seikkoihin aina työssä jaksamisesta työtehtävien mielekkääseen jakamiseen. Toisaalta tiimeissä voidaan kokea myös epäonnistumista esimerkiksi työnjaossa, roolien joustavuudessa tai vaikutusmahdollisuuksissa. (Sutela \& Lehto 2014.)

Tässä teoreettisessa artikkelissa tarkastelemme vuorovaikutusosaamista tavoiteorientoituneissa tiimeissä. Käytämme nimitystä ryhmä teoreettisissa yhteyksissä, kun kyse on pienryhmiä koskevasta tutkimustiedosta, joka soveltuu tiimiin. Ymmärrämme tiimin pienryhmän alakäsitteenä. Määrittelemme tiimin pieneksi keskinäisriippuvaiseksi ryhmäksi, jonka jäsenillä on yhteinen työhön liittyvä tavoite tai tavoitteita.

Vuorovaikutusosaaminen on yksi puheviestinnän alan keskustelluimmista ilmiöistä. Käsitteellä viitataan vakiintuneimman määritelmän mukaisesti niihin viestijän tietoihin, asenteisiin ja taitoihin, jotka mahdollistavat tavoitteiden saavuttamisen vuorovaikutuksessa tarkoituksenmukaisella tavalla (Spitzberg \& Cupach 1984). Vuorovaikutusosaamista on tutkittu esimerkiksi interpersonaalisessa vuorovaikutuksessa, pienryhmissä, esiintymisessä, opetusviestinnässä, organisaatioviestinnässä sekä teknologiavälitteisessä vuorovaikutuksessa. Vuorovaikutusosaaminen vaikuttaa monin tavoin ihmiselämään, esimerkiksi vuorovaikutussuhteiden laatuun, menestykseen opinnoissa tai työelämässä ja jopa psyykkiseen tai fyysiseen hyvinvointiin (Rickheit, Strohner \& Vorwerg 2010; Spitzberg 2013).

Kykyä viestiä pienryhmissä on perinteisesti työelämässä arvostettu. Ryhmätaitojen on katsottu edistävän muun muassa oppimista, kriittistä ajattelua ja työssä menestymistä sekä tiimityön laatua ja tuloksellisuutta (Beebe \& Barge 1994; Shockley-Zalabak 2015). Ryhmä- ja tiimityössä vuorovaikutusosaamista on kuitenkin tutkittu vähemmän kuin esimerkiksi kahdenvälisessä vuorovaikutuksessa tai esiintymisessä.

Artikkelin tavoitteena on edistää tiimin vuorovaikutusosaamisen teoriaa yhteisen vuorovaikutusosaamisen käsitteen avulla. Rakennamme käsitteellisen ehdotuksemme nelivaiheisesti. Ensin esitämme synteesin teoreettisista näkökulmista ryhmä- ja tiimivuorovaikutusosaamisen tutkimukseen. Toiseksi osoitamme tähänastisen tutkimuksen keskeiset puutteet erityisesti työelämän tiimien näkökulmasta. Kolmanneksi esittelemme monitieteisen tiimitutkimuksen teoreettisia edistysaskeleita, joiden avulla voidaan kehittää myös vuorovaikutusosaamisen tutkimusta. Lopuksi ehdotamme uutta yhteisen vuorovaikutusosaamisen käsitettä. Sen avulla voisi hyödyntää puheviestintätieteen lähialoilla tapahtunutta kehitystä ja korjata siten vuorovaikutusosaamisen tutkimuksen puutteita.

Artikkeli perustuu tiedonhakuun vuorovaikutusosaamisesta tiimissä. Erityisesti pyrimme löytämään sellaista kirjallisuutta, jossa vuorovaikutusosaamista ryhmissä ja tiimeissä on lähestytty teoreettisesti tai jossa esitetään relevanttia kritiikkiä vuorovaikutusosaamisen tutkimusta kohtaan. Teimme kirjallisuushaun myös tiimien vuorovaikutusosaamisen empiirisestä tutkimuksesta. Lisäksi esittelemme sellaista relevanttia tutkimusta, jossa tiimejä lähestytään emergenssin näkökulmasta. Tarkastelemamme tutkimus kohdistuu aikuisten työskentelyyn tehtäväkeskeisissä ryhmissä ja tiimeissä. Emme käsittele lapsiin, koululaisiin tai erityisryhmiin kohdistuvaa tutkimusta emmekä kulttuurienvälistä vuorovaikutusosaa- 
mista tai kielellistä osaamista tarkastelevaa tutkimusta.

\section{Vuorovaikutusosaamisen ulottuvuudet ja kriteerit ryhmässä}

Kärkevimmillään on todettu, että jokainen tutkija määrittelee vuorovaikutusosaamisen eri tavoin (Jablin \& Sias 2001, 820). Käsitteen määrittelyyn on kuitenkin vakiintunut yleisesti hyväksytty kehys, johon nojataan sekä teoreettisessa että empiirisessä tutkimuksessa. Kyse ei varsinaisesti ole teoriasta vaan pikemminkin mallintavasta ja käsitteellisestä työkalusta. Osaamisen katsotaan koostuvan affektiivisen, kognitiivisen ja behavioraalisen ulottuvuuden yhdistelmästä (esim. Rickheit, Strohner \& Vorwerg 2010; Spitzberg \& Cupach 1984). Ulottuvuudet ovat toisiaan mahdollistavia ja muokkaavia.

Affektiivinen ulottuvuus viittaa asenteisiin ja motivaatioon eli esimerkiksi siihen, haluaako viestijä osallistua vuorovaikutukseen vai vältellä sitä (Spitzberg 2013). Tiimeissä motivaatio tarkoittaa esimerkiksi jäsenten orientaatiota vuorovaikutusta kohtaan ja halukkuutta kontribuoida siihen.

Kognitiivinen ulottuvuus käsittää vuorovaikutukseen liittyviä tietosisältöjä kuten tietoa vuorovaikutuksen ominaispiirteistä erilaisissa tilanteissa ja suhteissa (Spitzberg 2013). Lisäksi se sisältää kyvyn suunnitella ja kontrolloida vuorovaikutuskäyttäytymistä, eli niin kutsutut metakognitiiviset tiedot ja taidot (Valkonen 2003, 36-37). Tiimiviestinnässä kognitiivinen ulottuvuus merkityksentyy esimerkiksi tiedoksi ja ymmärrykseksi vuorovaikutuksesta ja menettelytavoista tiimeissä sekä metakognitiiviseksi tiedoksi arvioida ja taidoksi säädellä omaa osuutta vuorovaikutuksessa.
Behavioraalista ulottuvuutta eli vuorovaikutustaitoja on tutkittu osaamisen osatekijöistä eniten. Vuorovaikutustaidoilla tarkoitetaan tavoiteorientoitunutta, opittua ja kontrolloitavissa olevaa vuorovaikutuskäyttäytymistä (Hargie 2011). Erilaisia vuorovaikutustaitoja on tunnistettu runsaasti, ja ne voidaan ryhmitellä neljään. Nämä ovat tarkkaavaisuuden (attentiveness), levollisuuden (composure), koordinoinnin (coordination) ja ilmaisevuuden (expressiveness) taidot. (Spitzberg 2013; Spitzberg \& Cupach 2002.)

Vuorovaikutusosaamista kaikkine ulottuvuuksineen kuvataan tyypillisesti kahdella kriteerillä. Ensimmäinen kriteeri määrittää, saavutetaanko vuorovaikutuksessa sille asetettuja tavoitteita tai toivottuja tuloksia (effectiveness) (Spitzberg 2013). Tavoitteet voivat olla sekä tehtäväkeskeisiä että relationaalisia. Tehtäväkeskeisiä tavoitteita ovat esimerkiksi laadukkaan päätöksen tekeminen tai tehtävään liittyvän muutoksen toteutuminen ja relationaalisia esimerkiksi tuen antaminen tai suhdekonfliktin ratkaiseminen. Toinen kriteeri määrittää vuorovaikutuksen tarkoituksenmukaisuutta (appropriateness) eli soveltuvuutta vuorovaikutustilanteeseen tai -suhteeseen. Kriteeri kytkeytyy vuorovaikutussuhteiden ja -tilanteiden normeihin ja odotuksiin (Rickheit, Strohner \& Vorwerg 2010, 26). Kriteerit ovat keskinäisriippuvaisia, ja molempien tulee täyttyä, jotta vuorovaikutusta voidaan pitää osaavana (Spitzberg 2013). Spitzbergin ja Cupachin (1984, 105) esittämän ja kirjallisuuteen vakiintuneen linjauksen mukaan osaava viestijä on sellainen, joka saavuttaa tavoitteitaan vuorovaikutuksessa tarkoituksenmukaisella tavalla.

Pienryhmien vuorovaikutusosaamisen tutkimuksessa on keskitytty tunnistamaan ja arvioimaan erityisesti ongelmanratkaisu- ja päätöksentekoprosesseissa tarvittavia vuorovai- 
kutustaitoja (esim. Beebe \& Barge 1994; Gouran 2003). Erityisesti funktionaalisen näkökulman (Gouran \& Hirokawa 1986) vaikutus on nähtävissä ryhmätaitotutkimuksessa (esim. Spitzberg 2011, 153-154). Näkökulman mukaan laadukkaassa ja tehokkaassa päätöksenteossa ryhmän tulee suorittaa neljä perusfunktiota: laatia toimintatavat, määritellä ja analysoida ongelma, luoda ja kehittää erilaisia ratkaisuvaihtoehtoja sekä arvioida niitä (Barge 2002; Morreale, Spitzberg \& Barge 2013, 183-184).

Beeben ja Bargen (1994) ryhmätaitojen arviointimittarissa vuorovaikutustaidot on jaettu ryhmäviestinnän tutkimukselle tyypillisesti tehtäväkeskeisiin ja relationaalisiin taitoihin. Tehtäväkeskeisiä taitoja ovat ongelman määritteleminen ja analysoiminen, ryhmän toiminnan arviointikriteerien tunnistaminen, ratkaisuvaihtoehtojen kehittäminen, tehtyjen ratkaisujen arvioiminen sekä tehtävään keskittymisen ylläpitäminen. Relationaalisia puolestaan ovat ilmapiirin ylläpitämisen sekä vuorovaikutuksen ja suhdekonfliktien hallinnan taidot. Jaottelua hyödynnetään yleisesti kirjallisuudessa (ks. Morreale, Spitzberg \& Barge 2013, 194-195; Shockley-Zalabak 2015). Gouran (2003) lisää tehtävä- ja suhdekeskeisten taitojen rinnalle menettelytapaan liittyvät suuntaamisen, muistuttamisen ja valppauden taidot.

\section{Tiimien vuorovaikutusosaamisen tutkimus ja sen puutteet}

Osaavan vuorovaikutuksen ulottuvuuksia ja kriteereitä on tutkittu runsaasti. Pienryhmien osalta on olemassa vakiintuneita näkemyksiä erityisesti niistä taidoista, joita ryhmässä tarvitaan. Kaikkiaan ryhmiin ja erityisesti tiimeihin kohdistuva vuorovaikutusosaamisen tutkimus on kuitenkin ollut muita konteksteja vähäisempää, ja varsinkin tiimiosaamisen tutkimuksessa voi nähdä useita puutteita, jotka ovat hidasta- neet tutkimuksen kehittymistä (ks. Beebe \& Barge 1994; Jablin \& Sias 2001; Shockley-Zalabak 2015; Thompson 2009). Nostamme puutteista esille taitopainotteisuuden, tilanteisuuden, dyadeja koskevan tiedon siirtämisen tiimeihin sekä yksilökeskeisyyden.

\section{Tutkimuksen taitopainotteisuus}

Suurin osa tiimien vuorovaikutusosaamistutkimuksesta on keskittynyt tunnistamaan ja luokittelemaan niitä taitoja, joita yksilöt tiimeissä tarvitsevat suoriutuakseen työstään (Hawkins \& Fillion 1999; Jablin \& Sias 2001). Näkökulmasta ja tutkimusalasta riippuen tiimitaitoihin luetaan päätöksenteko- ja ongelmanratkaisutaitojen ohella vaihtelevin käsitteellistyksin erilaiset projektinhallinta-, yhteistyö- ja vuorovaikutustaidot. Tiimitaitoja tarkasteleva tutkimus on kohdistunut mm. yksittäisiin ryhmäkeskusteluihin, koulutusten tai kurssien aikana kehittyviin tiimitaitoihin tai laajemmin ammatissa tarvittaviin tiimitaitoihin sekä tiimin sisällä että tiimin ja asiakkaan tai potilaan välillä. Tiimitaitojen tunnistaminen, opettaminen ja arvioiminen ovat herättäneet kiinnostusta lukuisten eri koulutusalojen tutkimuksessa, kun tiimissä työskentelemisen yleisyys ja tarvittavien taitojen merkitys on lisääntynyt.

Erilaisia mittareita viestintäkäyttäytymisen arviointiin tiimeissä on kehitetty jopa satoja, ja niitä on räätälöity etenkin erilaisten ammattispesifien tiimitaitojen arviointiin (Shockley-Zalabak 2015, 406-407) lukuisilla aloilla. Esimerkiksi terveydenhuollossa ja liiketaloudessa on runsaasti tutkimusta tiimitaidoista niin koulutuksen kuin ammatinharjoittamisen osalta. On selvitetty muun muassa taitojen oppimista ja opettamista (esim. Figl \& Motschnig-Pitrik 2007) sekä niiden vaikutusta tiimityöskentelyn koettuun tai havaittuun laatuun ja tuloksellisuuteen (esim. Gibon ym. 2013). Terveydenhuollon alalla taitojen kehitty- 
mistä tai taitotason määrittämistä on lähestytty esimerkiksi pyytämällä potilaita arvioimaan hoitotiimin taitoja CAT-T-arviointilomakkeella (communication assessment tool-team) (McCarthy ym. 2013) ja tarkastelemalla lyhytkoulutuksen vaikutusta hoitotiimin vuorovaikutustaitoihin (Gibon ym. 2013). Liiketalouden alalla on tarkasteltu tiimitaitojen opetuksen laatua ja tuloksellisuutta muun muassa toteuttamalla vertaisarviointia opiskelijaryhmissä (esim. Gueldenzoph \& May 2002) tai arvioimalla opiskelijoiden ryhmätaitojen kehittymistä kurssin aikana sekä itsearvioinnin, vertaisarvioinnin että opettajan arvioinnin näkökulmasta (esim. Winter 2000).

Taitojen määritelmät, abstraktiotasot, arviointimenetelmät ja -kriteeristöt vaihtelevat tutkimuksessa runsaasti (Shockley-Zalabak 2015). Tällainen vaihtelu on tyypillistä ammattispesifien taitojen arvioinnille yleensäkin (Spitzberg 2013). Taitopainotteisessa tutkimuksessa riskinä on pysähtyminen taitojen kartoittamisen ja luetteloinnin asteelle ja keskittyminen lähinnä työstä suoriutumiseen vähimmillään vaadittaviin vuorovaikutustaitoihin, niin kutsuttuun kynnysosaamiseen (threshold competence, Jablin ym. 1994). Tällöin kynnysosaamisen varaan kehittyvä korkeamman tason osaaminen jää huomiotta. Pitäisikin tutkia esimerkiksi sitä, millä perusteilla tiimin jäsenet olettavat viestintäkäyttäytymisestään seuraavan tietynlaisia tuloksia. (Jablin \& Sias 2001.) Tällainen tutkimus siirtäisi huomion myös osaamisen kognitiiviseen ja affektiiviseen ulottuvuuteen sekä tiimin vuorovaikutusosaamisen kokonaisuuteen, johon ei ole keskitytty riittävästi taito-orientoituneen tutkimuksen ohella.

\section{Tutkimuksen tilanteisuus}

Taito-orientoituneessa tutkimuksessa on suurimmaksi osaksi keskitytty yksittäisiin tilanteisiin ja päätöksentekotehtäviin, hyödyntäen usein opiskelijaryhmistä kerättyä aineistoa. Olisi tarve tutkia luonnollisia tiimejä pitkäkestoisesti. Työelämän muuttuvissa konteksteissa toteutettu pitkittäistutkimus, joka huomioisi sekä tehtäväkeskeiset että relationaaliset taidot ja suhteuttaisi niitä tiimin tuloksiin, toisi lisätietoa erityisesti pitkäaikaisten työelämän pitkäaikaisten tiimien osaamisesta (Shockley-Zalabak 2015, 423). Esimerkiksi formaali päätöksenteko on työelämässä yleensä vain yksi tiimien funktioista (Hawkins \& Fillion 1999; Marks, Mathieu \& Zaccaro 2001) ja sisältää pikemminkin pitkäkestoista merkityksentämistä yksittäisten päätöksentekotilanteiden sijaan.

Sen sijaan että keskityttäisiin tarkastelemaan taitoja tai taitotasoja tietyssä hetkessä, tulisi tutkimuksessa huomioida myös osaamistasojen vaihteleminen ajassa. Viestijöiden osaaminen voi karttua tai toisaalta heiketä esimerkiksi odottamattomien haasteiden edessä. Vaikka jotkin perustaidot olisivat suhteellisen pysyviä, on myös paljon sellaista osaamista, jonka taso vaihtelee ajan myötä. (Jablin \& Sias 2001, 828-829.)

\section{Dyadeja koskevan tiedon siirtäminen tiimeihin}

Ryhmien vuorovaikutusosaamisen tutkimukseen on sovellettu tietoa pääasiassa ei-organisatorisesta interpersonaalisesta tutkimuksesta (Shockley-Zalabak 2015). Osaaminen on siis käsitteellistetty yksilön tiedoiksi, taidoiksi ja asenteiksi, jotka mahdollistavat tavoitteiden saavuttamisen tarkoituksenmukaisella tavalla (Spitzberg \& Cupach 1984). Ryhmäviestintätaitoja on esimerkiksi pidetty samoina kuin kahdenvälisessä vuorovaikutussuhteessa tarvittavia (Littlejohn \& Jabusch 1982). Joiltain osin ne voivatkin olla, mutta toisaalta kahdenvälisen vuorovaikutuksen ja ryhmäviestinnän pitäminen samanlaisina johtaa teoreettisiin ongelmiin (Jablin 1994, 33). Ryhmä on vuorovaikutuksel- 
taan dyadia kompleksisempi: se sisältää useita samanaikaisia vuorovaikutussuhteita (Poole 2007), limittyvää ja päällekkäistä osallistumista sekä useamman osapuolen samanaikaista itsearviointia ja toisten arviointia. Esimerkiksi kuunteleminen on ryhmässä vaikeampi taito kuin dyadissa (Hawkins \& Fillion 1999).

Perusolettamukset dyadisen vuorovaikutusosaamisen osatekijöistä ja kriteereistä pätevät todennäköisesti ryhmässä (ks. Valkonen 2003, 45), mutta esimerkiksi mittareita ja arviointitapoja ei voida sellaisinaan siirtää ryhmään sen kompleksisuuden vuoksi (Keyton 1986). On tarpeen kehittää ja testata erityisesti tiimiosaamista koskevaa teoriaa, etenkin jos tarkastelua halutaan laajentaa yksilötasosta myös ryhmän ja/tai organisaation vuorovaikutusosaamisen tutkimukseen (Shockley-Zalabak 2015, 422).

\section{Yksilökeskeisyys}

Suurin osa vuorovaikutusosaamisen tutkimuksesta on kohdistunut yksilötasoon. Kuitenkaan yksilötasolla tehdyt havainnot eivät kuvaa tiimin osaamista riittävällä tavalla. Dyadi tai ryhmä on nähty lähinnä kontekstina, jossa yksilöiden osaaminen tulee ilmi. Poikkeuksena tästä on kahdenvälisiin lähisuhteisiin painottunut relationaalisen osaamisen tutkimus (Wiemann ym. 1997), jossa osaaminen on määritelty suhteessa rakentuvana. Ryhmän tason huomioimista ryhmäosaamisen tutkimuksessa on peräänkuulutettu (esim. Beebe \& Barge 1994; Jablin \& Sias 2001; Shockley-Zalabak 2015). Osaamisen sijainnin täsmentämistä ja yksilöpainotteisuuden haastamista on kutsuttu osaamistutkimuksen perimmäiseksi ratkaisemattomaksi haasteeksi (Spitzberg \& Changnon 2009, 44).

Ryhmätason tarkastelu mahdollistaisi keskittymisen sosiaalisen todellisuuden rakentumiseen ja elementteihin, jotka eivät ole täysin jäljitettävissä yksilöihin (Poole 2007, 358). Esimerkiksi Jablin ja Sias (2001) ovat ehdottaneet vuorovaikutusosaamisen tarkastelemista eri tasot huomioiden. Heidän mukaansa tiimillä voi olla vuorovaikutusosaamista, joka ei ole samanlaista kuin se osaaminen, jota jäsenillä yksilöinä on. Esimerkiksi erilaiset strukturaatioprosessit sekä fantasiateemat eli yhteinen menneisyyden ja tulevaisuuden dramatisointi voivat muokata myös vuorovaikutusosaamista koko ryhmän tasolla. (Jablin \& Sias 2001, 826.) Niin ikään Shockley-Zalabak (2015) sekä Beebe ja Barge (1994) ovat ehdottaneet, että osaamistutkimuksen tulisi tavoittaa sekä yksilön että ryhmän taso. Yksilötasolla oletuksena on, että jäsen voidaan tunnistaa osaavaksi, vaikkei ryhmän vuorovaikutus kokonaisuudessaan sellaista olisikaan. Ryhmätason tarkastelu puolestaan merkitsisi esimerkiksi jäsenten kollektiivisen vuorovaikutuskäyttäytymisen analysointia suhteessa tiimin tuloksiin.

Alustavia askeleita on otettu yksilö- ja ryhmätason huomioivassa empiirisessä tutkimuksessa. Esimerkiksi Thompson (2009) tarkasteli etnografisessa tutkimuksessaan sitä, millaiset vuorovaikutusprosessit edistävät tai heikentävät pitkäaikaisen tiimin jäsenten kokemusta vuorovaikutusosaamisen kollektiivisuudesta. Edistäviksi prosesseiksi tunnistettiin $\mathrm{mm}$. läsnäolon osoittaminen, reflektoiva puhe ja informaali vuorovaikutus, kun taas esimerkiksi negatiivisen huumorin, tylsyyden viestimisen ja toisen asiantuntijuuden kyseenalaistamisen todettiin estävän osaamisen kollektiivista kokemista.

\section{Emergentit ilmiöt tiimeissä}

Vuorovaikutusosaamista voitaisiin tarkastella myös niin, että tutkimuksessa otettaisiin huomioon paitsi yksilö- ja ryhmätaso myös se organisaatio tai yhteisö, jossa tiimit toimivat ja johon ne kuuluvat (Jablin \& Sias 2001; 
Shockley-Zalabak 2015). Vuorovaikutusosaamista siis muodostuisi ja ilmenisi monitasoisesti. Tällaista tutkimusta kutsutaan monitasoiseksi tiimi-ilmiöiden tutkimukseksi (ks. Kozlowski 2013). Tätä näkökulmaa vuorovaikutusosaamiseen ei tietääksemme ole yksittäisiä huomiointeja lukuun ottamatta edistetty teoreettisesti tai huomioitu empiirisessä tutkimuksessa. Sen sijaan etenkin tällä vuosituhannella erilaisten tiimi-ilmiöiden tutkimus monitasoisesti on kehittynyt runsaasti, joskin puheviestintätieteen ulkopuolella. Esimerkiksi psykologian, HR-tutkimuksen ja johtamistutkimuksen aloilla on osoitettu kasvavaa kiinnostusta muun muassa tiedonhallinnan, normien ja oppimisen monitasoista tarkastelua kohtaan. Etenkin monitasoisessa tiimitutkimuksessa hyödynnetyn emergenssin käsitteen avulla voitaisiin tarttua esille nostamiimme tutkimuksen puutteisiin. Esittelemme seuraavaksi emergenssin käsitettä tiimi-ilmiöiden tutkimuksessa erityisesti yksilö- ja ryhmätasoihin keskittyen. Pohjustus on keskeinen osa yhteisen vuorovaikutusosaamisen käsitteellistämistä.

Organisaatiotutkimuksessa on perinteisesti jaettu ilmiöt mikro-, meso- ja makrotasoille eli yksilön, ryhmän ja organisaation tasoille (Rousseau 1985). Sittemmin tutkimuksessa on kiinnostuttu tiimeistä kompleksisina systeemeinä, joissa jokainen taso muodostaa oman systeeminsä ja on samalla upotettuna ylempiin tasoihin (Poole 2014, 51). Tasot myös vaikuttavat toisiinsa kaksisuuntaisesti (Kozlowski ym. 2013). Esimerkiksi tiimin tasolle muodostuneet normit vaikuttavat sen jäseniin, ja samanaikaisesti jäsenten keskinäiset vuorovaikutusprosessit vaikuttavat siihen, millaisiksi tiimin tason normit muotoutuvat. Tällaista ilmiöiden muodostumista voidaan tutkia emergenssin käsitteen kautta. Käsitteen juuret ovat systeemiteoriassa, ja sitä on hyödynnetty muun muassa biologiassa, sosiologiassa sekä tieteen ja mielen filosofiassa (Fulmer \& Ostroff 2015). Erittelemme seuraavaksi käsitteen merkitystä tiimitutkimuksessa.

Tiimissä emergenssin käsite kuvaa prosessia, jossa yksilölliset piirteet tai toimintatavat ilmenevät, muokkautuvat ja yhdentyvät tiimin tason rakenteina. Nämä rakenteet eivät ole täysin palautettavissa yksilölähtökohtiinsa tai selitettävissä yksilötason elementtien yhdistelmällä, sillä systeemiteoreettisen perusperiaatteen mukaisesti ylemmän tason kokonaisuudet voivat olla enemmän tai muuta kuin osiensa summa. (Kozlowski ym. 2013; ks. myös Poole 2014, 52-54.) Suurta osaa kognitiivisista, affektiivisista ja behavioraalisista tiimi-ilmiöistä voidaan pitää luontaisesti emergentteinä ja tutkia sellaisina (Kozlowski 2013, 261; 265). Tiimi voi esimerkiksi tietää kokonaisuutena jotakin sellaista, joka ei ole palautettavissa yksilötason tietosisältöihin. Affektiivisista ilmiöistä on tutkittu esimerkiksi tiimipystyvyyttä, kollektiivista identiteettiä sekä tiimikoheesiota. Käyttäytymisestä on tutkittu esimerkiksi tiimin koordinaatiota ja itsesäätelyprosesseja. (Fulmer \& Ostroff 2015; Kozlowski ym. 2013.)

Emergenttien ilmiöiden tutkimuksesta pisimmälle on kehittynyt tiimikognition eli tiimin tasolle muodostuneiden kognitiivisten rakenteiden tutkimus. Siinä missä yksilö kerää, tulkitsee ja varastoi tietoa sisäisesti, ryhmä varastoi ja muokkaa tietoa jäsentensä vuorovaikutuksessa (Salas, Cooke \& Rosen 2008, 541). Arkikokemuksessa tiimikognitio merkityksentyy esimerkiksi yhteisymmärryksenä tai "samalla aaltopituudella" olemisena. Tiimikognitiosta on tutkittu erityisesti yhteisiä mielen malleja (shared/team mental models). Empiirinen tutkimus on osoittanut, että yhteinen, organisoitu ja realistinen kognitiivinen representaatio resursseista, tehtävästä ja keskinäisistä suhteista vaikuttaa positiivisesti tiimin tuloksellisuuteen. 
Tällöin jäsenet ymmärtävät tehtäviensä laajuuden ja vaatimukset sekä työskentelyn koordinoinnin samalla tavalla. (Ks. koontia Mohammed, Ferzandi \& Hamilton 2010.) Vastaavasti paikkansa pitävän ja kattavan yhteisen mielen mallin puute voi johtaa heikkoon koordinointiin, koheesioon ja suoritukseen sekä yleiseen tyytymättömyyteen tiimin jäsenten välillä (Matteson 2015).

Tiimitutkimuksen näkökulmasta emergenssiä voidaan luonnehtia kolmen keskeisen fokuksen kautta. Nämä ovat ilmiöiden monitasoisuus, prosessuaalisuus sekä temporaalisuus. (Fulmer \& Ostroff 2015; Kozlowski ym. 2013.) Monitasoisuudella viitataan siihen, että emergentit ilmiöt tiimeissä sisältävät aina alemman tason, jolla ne saavat alkunsa, kuten yksilön kognition, motivaation ja/tai käyttäytymisen. Lisäksi ne sisältävät korkeamman tason, jolla kollektiivinen ilmiö, kuten yhteinen identiteetti, tulee näkyväksi. Prosessuaalisuudella tarkoitetaan niin kutsutun input-process-output-mallin mukaisesti sitä, että emergentti ilmiö muodostuu jäsenten tiimiin tuomien yksilöllisten syötteiden vaikuttuessa vuorovaikutusprosesseissa toisistaan (Fulmer \& Ostroff 2015). Esimerkiksi tietosisällöistä ei voi kehittyä ryhmän tasoisia, elleivät tiimin jäsenet jaa ja kehitä sisältöjä vuorovaikutuksessa.

Emergentit ilmiöt ovat temporaalisia eli aikasidonnaisia. Ne vaativat aikaa kehittyäkseen, ja tämä kehitys tapahtuu jatkuvassa syklisessä prosessissa (Fulmer \& Ostroff 2015; Kozlowski ym. 2013). Esimerkiksi tiimin yhteiseen pystyvyyskäsitykseen vaikuttavat yksilötekijät, jotka muokkaavat vuorovaikutusta, jossa muodostuu emergentti käsitys yhteisestä pystyvyydestä. Tämä käsitys toimii jälleen syötteenä tiimin tulevalle toiminnalle ja vuorovaikutusprosesseille, mutta kuitenkin se vielä ajan myötä to- dennäköisesti muuntuu. (Marks, Mathieu \& Zaccaro 2001, 357.)

Emergenttejä ilmiöitä voidaan tutkia epäsuorasti tai suorasti sekä laadullisesti tai määrällisesti. Epäsuorissa laadullisissa ja määrällisissä tutkimuksissa toteutetaan retrospektiivistä aineistonkeruuta esimerkiksi haastatteluin tai kyselyin, ja tulkintoja emergenssistä tehdään sen jälkeen, kun sitä on oletetusti jo tapahtunut. Suorissa menetelmissä puolestaan pyritään kuvaamaan tai mallintamaan emergenssin prosessia. Laadullisia menetelmiä edustavat esimerkiksi etnografiset, havainnointiin ja osallistuvaan toimintaan perustuvat tutkimukset (Kozlowski ym. 2013). Erityisesti luonnollisten ryhmien, kuten työelämän tiimien, tarkastelu mahdollistaakin temporaalisten ilmiöiden tarkastelun (Arrow ym. 2005). Määrälliset suorat tutkimukset perustuvat pääasiassa formaaliin ja laskennalliseen mallintamiseen. Siinä pyritään yksinkertaistamaan emergenssin taustatekijöitä ja logiikkaa laskennalliseksi simulaatioksi, jonka toimintaa voidaan esimerkiksi verrata todellisiin ryhmiin. (Kozlowski ym. 2013.)

Monitasoisuuden ja systeemisyyden huomioivaa näkökulmaa on kutsuttu yhdeksi merkittävimmistä edistyksistä viime vuosikymmenten tiimitutkimuksessa (Mohammed \& Hamilton 2013). Sitä ei kuitenkaan ole toistaiseksi juuri huomioitu vuorovaikutusosaamisen tutkimuksessa. Tarve monitasoiseen tutkimukseen on nostettu esille (esim. Jablin \& Sias 2001; Shockley-Zalabak 2015). Esittelemme seuraavaksi oman ehdotuksemme monitasoisen tarkastelun edistämiseksi tiimien vuorovaikutusosaamisen tutkimuksessa. 


\section{Yhteisen vuorovaikutusosaamisen käsitteellistäminen}

Vuorovaikutusosaamisen tarkastelu yksilötasolla, tilanteisesti, taitopainotteisesti ja dyadista tutkimustietoa soveltaen on estänyt tutkimusta kehittymästä suuntaan, joka auttaisi selvittämään tiimin vuorovaikutusosaamisen muodostumista ja ulottuvuuksia parhaalla mahdollisella tavalla. Viime vuosina ymmärrys tiimi-ilmiöiden emergenssistä eli niiden monitasoisuudesta, temporaalisuudesta ja prosessuaalisuudesta on kehittynyt lupaavasti. Laaja tutkimustieto tuo tukea sille, että myös vuorovaikutusosaamista ja sen osatekijöitä tiimeissä voitaisiin tutkia tästä näkökulmasta. Edistämme tutkimusta tuomalla tiimin vuorovaikutusosaamisen tutkimukseen yhteisen vuorovaikutusosaamisen käsitteen. Määrittelemme tiimin yhteisen vuorovaikutusosaamisen emergentiksi osaamiseksi, joka on 1) luonteeltaan sekä yksilöllistä että tiimin tasolle muodostuvaa (monitasoisuus), 2) sosiaalisesti vuorovaikutusprosesseissa konstruoitavaa (prosessuaalisuus) sekä 3) ajan myötä kehittyvää ja vaihtelevaa (temporaalisuus).

Vuorovaikutusosaamisella on yksilöllinen perusta. Kaiken viestinnän taustalla ovat erilaiset yksilölliset prosessit, joissa tulkitaan viestejä ja osallistutaan vuorovaikutukseen (Rickheit, Strohner \& Vorwerg 2010). Tiimin jäsenillä on aina eroja osaamisalueissaan ja -tasoissaan. Väitämme, että tiimissä vuorovaikutusosaaminen ei kuitenkaan ole vain yksilöistä lähtöisin tai täysin heihin palautettavissa. On olemassa vielä sellaista tiimin yhteistä vuorovaikutusosaamista, jota tiimi rakentaa, säätelee, muokkaa ja käyttää vuorovaikutusprosesseissaan.

Mikäli pyritään tekemään päätelmiä koko tiimin osaamisesta vain yksilötiedon varassa, ollaan vaarassa sortua päättelyn ns. komposi- tio- tai divisioharhoihin (ks. van Eemeren \& Garssen 2009). Tämä voi tapahtua esimerkiksi pääteltäessä yksilön osaamisesta tai yhteen lasketuista osaamistasoista ryhmän tason osaaminen (kompositioharha) tai päättelemällä suoraan ryhmän toiminnasta se, mitä jäsenet yksilöinä osaavat (divisioharha). Päättelyvirheistä käytetään usein esimerkkinä joukkueurheilua: vaikka jokainen pelaaja olisi yksilönä hyvä, ei joukkue välttämättä kokonaisuutena ole hyvä. Siispä vaikka tiimin jäsenet todettaisiin yksilöinä osaaviksi, ei näiden arvioiden yhdistäminen tai esimerkiksi keskiarvon laskeminen ole yhtä kuin kuvaus ryhmän osaamisesta kokonaisuutena (Keyton 1986). Yksilötasolla vuorovaikutusosaaminen tiimissä käsittää viestinnälliset tiedot, taidot ja asenteet, jotka mahdollistavat tarkoituksenmukaisen ja tavoitteita saavuttavan osallistumisen vuorovaikutukseen. Ryhmän tasolla tarkasteltuna vuorovaikutusosaaminen on myös osaamisen yhteistä neuvottelemista, säilyttämistä ja uudelleen luomista suhteessa tilanteisiin, vaatimuksiin, tehtäviin ja menneestä opittuun. Tämä ryhmän tason osaaminen muotoutuu ajan myötä vuorovaikutusprosesseissa.

\section{Tiimin yhteisen vuorovaikutusosaamisen tutkimusmahdollisuudet}

Osaamisulottuvuuksien näkökulmasta yhteinen vuorovaikutusosaaminen avaa kiinnostavia tutkimusmahdollisuuksia. Kognitiivisen ulottuvuuden osalta voidaan tutkia esimerkiksi sitä, mitä tiimi yhteisesti pitää osaavana vuorovaikutuksena ja millaista osaamista tai sen puutteita tiimillä sen mielestä on. Affektiivisen ulottuvuuden osalta voitaisiin tutkia tiimin asennoitumista vuorovaikutusosaamista ja sen kehittämistä kohtaan. Behavioraalista ulottuvuutta voitaisiin tutkia tarkastelemalla esimerkiksi sitä, miten tiimin tieto ja näkemys osaa- 
misesta ja asennoituminen sitä kohtaan näkyy sen yhteisessä viestintäkäyttäytymisessä.

Ryhmätason osaamisen tunnistaminen tai siitä päätelmien tekeminen on haastava tehtävä. Pfisterin (2009, 21-22) mukaan yksilöistä yhteisempään näkökulmaan siirtyminen vuorovaikutusosaamistutkimuksessa edellyttäisi erityisesti yhteisten merkitysten tarkastelua, vaikkakin metodologisesti tämä on haastavampaa kuin esimerkiksi kysely- tai arviointiaineiston kerääminen jäseniltä. Keskeistä yhteisen vuorovaikutusosaamisen ymmärtämisessä lienee erityisesti pitkäkestoinen havainnointitutkimus, joka mahdollistaisi osaamisen kehittymisen tarkastelun tiimin yhteisten tilanteiden ja niissä ilmenevän vuorovaikutuksen kautta (vrt. Fulmer \& Ostroff 2015; Matteson 2015). Toisaalta esimerkiksi haastattelututkimuksella voitaisiin tavoittaa tiimin yhteisiä merkityksenantoja osaamiselle.

Tiimin yhteisen vuorovaikutusosaamisen tutkimuksen etuina voidaan pitää temporaalisuuden ja prosessuaalisuuden huomioimista, osaamistutkimuksen ideologisten lähtökohtien haastamista sekä kontekstuaalisuuden huomioimista. Lisäksi se antaa mahdollisuuden monitieteisyyteen sekä käytännön kehitys- ja koulutustyön edistämiseen.

Temporaalisuus ja prosessuaalisuus ovat mukana yhteisen vuorovaikutusosaamisen tutkimuksessa silloin, kun tarkastellaan tiimejä, joilla on sekä menneisyys että oletettu tulevaisuus. Tällöin tiimin toimintaa leimaavat menneiden kokemusten sekä tulevaisuuteen liittyvien odotusten merkityksentäminen, tavoitteiden uudelleen muotoilu ja täsmentäminen sekä osaamisen jatkuva kehittäminen. Tiimien elinkaaren tavoittava pitkittäistutkimus voisi tuottaa monipuolista tietoa osaamisen yhteisyyden muovautumisesta (vrt. Kozlowski ym. 2013,
586). Esimerkiksi Jablin (1994, 39-40) on ehdottanut, että organisaatioiden uusien jäsenten vuorovaikutusosaamisen kehittymistä voitaisiin tutkia pitkittäisesti heidän omaksuessaan organisaation vuorovaikutuskäytänteitä. Tiimien näkökulmasta kiinnostavaa olisi tutkia esimerkiksi sitä, miten uuden tiimin jäsenet alkavat sovittaa osaamisalueitaan yhteen ja kehittää osaamistaan yhteisesti muotoutuvien kriteerien ja odotusten mukaisiksi. Sen sijaan lyhytaikaisten ryhmien ja tiimien (kuten yksittäisten päätöksentekoryhmien tai lyhytaikaisten projektitiimien) osalta lienee hyödyllisempää keskittyä yksilöllisiin osaamisalueisiin, sillä niissä ei todennäköisesti ehdi kehittyä emergenssiä.

Kaikki vuorovaikutusosaamisen tutkimus edellyttää aina ideologisia valintoja - käsitehän kytkeytyy arvostuksiin sekä päätelmiin siitä, mikä on hyvää vuorovaikutusta (Jablin \& Sias 2001, 831-832; Spitzberg 2000). Yksilölähtöisen tutkimuksen voi nähdä heijastelevan individualistista ideologiaa, jonka mukaisesti yksilö on vastuussa osaamisestaan, onnistumisistaan ja epäonnistumisistaan (ks. Boreham 2004; Pfister 2009). Kuitenkin tiimeihin työn organisoinnin muotona yhdistetään yleensä työskentelyn, tavoitteiden ja vastuun jonkinasteinen yhteisyys. Yhteisen vuorovaikutusosaamisen tutkimus tukisi tätä näkemystä ja toisi lisätietoa päivittäisessä työssä yhteisesti luoduista osaamiseen liittyvistä merkitysrakenteista ja toimintatavoista.

Osaaminen on aina kontekstisidonnaista: jossakin kontekstissa osaavaksi tulkittu vuorovaikutuskäyttäytyminen ei välttämättä tule tulkituksi samoin toisessa (Beebe \& Barge 1994, 258). Erilaisissa tiimeissä tarvittava osaaminen ei välttämättä ole samansisältöistä. Tutkimuksen tulisikin huomioida paremmin se, että tietyssä tilanteessa on mahdollista toimia osaavasti lukuisilla eri tavoilla (Jablin 1994). Tiimit voi- 
vat kehittää monia tapoja saavuttaa tavoitteita tarkoituksenmukaisesti vuorovaikutuksessa. Jonkinasteisia todennäköisyyksiä sille, mitä tietynlaisesta vuorovaikutuskäyttäytymisestä seuraa erilaisissa konteksteissa, on toki olemassa (Spitzberg 2000, 110), eikä vuorovaikutusosaamista ole mielekästä määritellä uudelleen kunkin vuorovaikutussuhteen, tilanteen tai kontekstin mukaisesti. Toisaalta esimerkiksi tiimien osaamisen ja tuloksellisuuden välisen suhteen todentaminen on toistaiseksi ollut haastavaa. Tietoa on lähinnä yksilötason tutkimuksesta, ja osaamisen ja tuloksellisuuden määritelmät vaihtelevat runsaasti. (Shockley-Zalabak 2015.) Tarvitaan lisätietoa tiimien osaamisen ilmenemismuodoista ja kontekstuaalisista vaatimuksista, ja tässä yhteisen vuorovaikutusosaamisen käsite voi olla avainasemassa.

Yhteisen vuorovaikutusosaamisen tutkimus edistäisi ryhmäviestinnän teorianmuodostusta, erityisesti osaamisen sijainnin ja yksilön ja ryhmän välisen suhteen osalta. Se voisi tuoda vuorovaikutusosaamisen tutkimusta tiiviimpään keskusteluyhteyteen muiden alojen tiimitutkimuksen kanssa, joilla sivutaan usein myös vuorovaikutuksen tai siihen liittyvien taitojen sisältöjä (esim. Mohammed, Ferzandi \& Hamilton 2010). Tuloksena voisi olla uudenlaisia tutkimusasetelmia ja menetelmällisiä laajennuksia. Yhteisen vuorovaikutusosaamisen tutkimus syventäisi monitasoisuuden ymmärrystä puheviestintätieteen näkökulmasta. Tämän lisäksi se voisi täydentää laajemminkin tietämystä siitä, miten erilaiset emergentit prosessit vaikuttavat tiimityön laatuun ja sujuvuuteen. On myös tärkeää pohtia sitä, mihin työelämän tiimien arviointi ja kehittäminen tulisi pohjata - yksilöosaamiseen vai myös koko tiimin vuorovaikutusosaamiseen ja siihen liittyvien resurssien parantamiseen (ks. Laajalahti 2014, 164). Tutkimustietoa hyödyntämällä voitaisiin auttaa tiimejä analysoimaan ja kehittämään omaa yhteistä osaamistaan.

Tessa Horila valmistelee puheviestinnän alan väitöskirjaansa Maarit Valon ohjauksessa. Väitöskirjatyötä ovat tukeneet Suomen Akatemia (hanke 138186), Ella ja Georg Ehrnroothin säätiö sekä Työsuojelurahasto (hanke 115257).

\section{Kirjallisuus}

Arrow, H., Henry, K. B., Poole, M. S., Wheelan, S., \& Moreland, R. 2005. Traces, trajectories, and timing: The temporal perspective on groups. Teoksessa M. S. Poole \& A. B. Hollingshead (toim.) Theories of small groups: Interdisciplinary perspectives. Thousand Oaks: Sage, 313-368.

Barge, J. K. 2002. Enlarging the meaning of group deliberation: From discussion to dialogue. Teoksessa L.R. Frey (toim.) New directions in group communication. Thousand Oaks: Sage, 159-178.

Beebe, S. A., \& Barge, J. K. 1994. Small group communication. Teoksessa W. G. Christ (toim.) Assessing communication education: A handbook for media, speech and theatre educators. New York: Routledge, 257-290.

Boreham, N. 2004. A theory of collective competence: Challenging the neo-liberal individualization of performance at work. British Journal of Educational Studies 52 (1), 5-17.

van Eemeren, F. H. \& Garssen, B. 2009. The fallacies of composition and division revisited. Journal of Reasoning and Argumentation 1 (1), 23-42.

Figl, K. \& Motschnig-Pitrik, R. 2007. Developing team competence in technology enhanced courses. Proceedings of World Conference on Educational Multimedia, Hypermedia \& Telecommunications (ED-MEDIA). Vancouver: AACE.

Fulmer, C. A. \& Ostroff, C. 2015. Convergence and emergence in organizations: An integrative framework and review. Journal of Organizational Behavior. Julkaistu online first. Doi: 10.1002/ job.1987.

Gibon, A-S., Merckaert, I., Liénard, A., Libert, Y., Delvaux, N., Marchal, S., Etienne, A-M., Reynaert, C., Slachmuylder, J-L., Scalliet, P., Van Houtte, P., Coucke, P., Salamon, E. \& Razavi, D. 2013. Is it possible to improve radiotherapy team members' communication skills? A randomized study assessing the efficacy of a 38-h communication skills training program. Radiotherapy and Oncology 109, 170-177. 
Gouran, D. S. 2003. Communication skills for group decision making. Teoksessa J. O. Greene \& B. R. Burleson (toim.) Handbook of communication and social interaction skills. New Jersey: Lawrence Erlbaum, 835-870.

Gouran, D. S. \& Hirokawa, R. Y. 1986. Counteractive functions of communication in effective group decision-making. Teoksessa R.Y. Hirokawa \& M. S. Poole (toim.) Communication and group decisionmaking. Beverly Hills: Sage, 81-92.

Gueldenzoph, L. E. \& May, G. L. 2002. Collaborative peer evaluation: Best practices for group member assessments. Business Communication Quarterly 65 (1), 9-20.

Hargie, O. 2011. Skilled interpersonal communication. Research, theory and practice. Viides painos. London: Routledge.

Hawkins, K. W. \& Fillion, B. P. 1999. Perceived communication skill needs for work groups. Communication Research Reports 16 (2), 164-174.

Jablin, F. M. 1994. Communication competence: An organization assimilation perspective. Teoksessa L. Waes, E. Woudstra \& P. van den Hoven (toim.) Functional communication quality. Amsterdam: Rodopi, 30-41.

Jablin, F. M. \& Sias, P. 2001. Communication competence. Teoksessa F. Jablin \& L. Putnam (toim.) The new handbook of organizational communication: Advances in theory, research and methods. Thousand Oaks: Sage, 819-864.

Keyton, J. 1986. Extrapolating a dyadic model to small group methodology: Validation of the Spitzberg and Cupach model of communication competence. Paper presented at the annual meeting of the Speech Communication Association, Chicago.

Kozlowski, S. W. J. 2013. Groups and teams in organizations: Studying the multilevel dynamics of emergence. Teoksessa M. S. Poole \& A. B Hollingshead (toim.) Research methods for studying groups and teams. New York: Routledge, 260-283.

Kozlowski, S. W. J., Chao, G. T., Grand, J. A., Braun, M. T. \& Kuljanin, G. 2013. Advancing multilevel research design: Capturing the dynamics of emergence. Organizational Research Methods 16 (4), 581-615.

Laajalahti, A. 2014. Vuorovaikutusosaaminen ja sen kehittyminen tutkijoiden työssä. Jyväskylän yliopisto. Jyväskylä Studies in Humanities 225.

Littlejohn, S. W. \& Jabusch, D. M. 1982. Communication competence: Model and application.
Journal of Applied Communication Research 10 (1), 29-37.

Marks, M. A., Mathieu, J. E. \& Zaccaro, S. J. 2001. A temporally based framework and taxonomy of team processes. Academy of Management Review 26 (3), 356-376.

Matteson, M. 2015. Capturing shared mental models: An approach for bona fide groups. Journal of Librarianship and Information Science 47 (1), 56-70.

McCarthy, D. M., Ellison, E. M., Venkatesh, A. K., Engel, K. R., Cameron, K. A., Makoul, G. \& Adams, J. G. 2013. Emergency department team communication with the patient: The patients perspective. Administration of Emergency Medicine 45 (2), 262-270.

Mohammed, S., Ferzandi, L., \& Hamilton, K. 2010. Metaphor no more: A 15-year review of the team mental model construct. Journal of Management 36, 876-910.

Mohammed, S. \& Hamilton, K. 2013. Studying team cognition: The good, the bad, and the practical. Teoksessa M. S. Poole \& A. B Hollingshead (toim.) Research methods for studying groups and teams. New York: Routledge, 132-153.

Morreale, S. P., Spitzberg, B. H. \& Barge, J. K. 2013. Communication: Motivation, knowledge, skills. 3. painos. New York: Peter Lang.

Pfister, R. 2009. Communicative competence: A useful concept or a product of hegemony? Paper presented at the annual meeting of the NCA 95th Annual Convention, Chicago.

Poole, M. S. 2007. The small group should be the fundamental unit of communication research. Teoksessa R. T. Craig \& H. L. Muller (toim.) Theorizing communication. Readings across traditions. Thousand Oaks: Sage, 357-360.

Poole, M. S. 2014. Systems theory. Teoksessa L. L. Putnam \& D. K. Mumby (toim.) The Sage handbook of organizational communication: Advances in theory, research, and methods. Thousand Oaks: Sage, 49-74.

Rickheit, G., Strohner, H., \& Vorwerg, C. 2010. The concept of communicative competence. Teoksessa G. Rickheit \& H. Strohner (toim.) Handbook of communication competence. Berlin: Mouton de Gruyter, 15-64.

Rousseau, D. M. 1985. Issues of level in organizational research: Multi-level and cross-level perspectives. Research in Organizational Behavior 7, 1-37. 
Salas, E., Cooke, N. J., \& Rosen, M. A. 2008. On teams, teamwork, and team performance: Discoveries and developments. Human Factors 50, 540-547.

Shockley-Zalabak, P. S. 2015. Communication competence in organizations and groups: Historic and emerging perspectives. Teoksessa A. F. Hannawa \& B. H. Spitzberg (toim.) Communication competence. Berlin: Walter de Gruyter, 397-430.

Spitzberg, B. H. 2011. The interactive media package for assessment of communication and critical thinking (IMPACCT $\odot$ ): Testing a programmatic online communication competence assessment system. Communication Education 60 (2), 145-173.

Spitzberg, B. H. 2013. (Re)Introducing communication competence to the health professions. Journal of Public Health Research 2 (23), 126-135.

Spitzberg, B. H., \& Cupach, W. R. 1984. Interpersonal communication competence. Beverly Hills: Sage.

Spitzberg, B. H. \& Cupach, W. R. 2002. Interpersonal skills. Teoksessa M. L. Knapp \& J. A. Daly (toim.) Handbook of interpersonal communication. 3. painos. Thousand Oaks: Sage, 564-611.

Spitzberg, B. H., \& Changnon, G. 2009. Conceptualizing intercultural competence. Teoksessa D. K. Deardorff (toim.) The Sage handbook of intercultural competence. Thousand Oaks: Sage, $2-52$.

Sutela, H. \& Lehto, A-M. 2014. Työolojen muutokset 1977-2013. Helsinki: Tilastokeskus.

Thompson, J. L. 2009. Building collective communication competence in interdisciplinary research teams. Journal of Applied Communication Research 37 (3), 278-297.

Valkonen, T. 2003. Puheviestintätaitojen arviointi: näkökulmia lukiolaisten esiintymis- ja ryhmätaitoihin. Jyväskylän yliopisto. Jyväskylä Studies in Humanities 7.

Wiemann, J. M., Takai, J., Ota, H. \& Wiemann, M. O. 1997. A relational model of communication competence. Teoksessa B. Kovačić (toim.) Emerging theories of human communication. Albany: State University of New York Press, 25-44.

Winter, J. K. 2000. Student evaluation of a learning exercise designed to develop effective meeting skills. Journal of Education for Business 75 (4), 210-213. 